\title{
Epistaxis among children in Lower Egypt: frequency and risk factors
}

\author{
Hanaa S. Said MD ${ }^{1}$, Marwa M. Mohasseb MD ${ }^{2}$ \\ ${ }^{1 *}$ Department of Family Medicine, Faculty of Medicine, Zagazig University. \\ ${ }^{2}$ Department of Family Medicine, Faculty of Medicine, Menoufia University.
}

\section{Abstract:}

Background: Epistaxis, or nosebleeds, is a common complaint especially in young children. Most of the risk factors causing epistaxis are preventable or modifiable, so identification of these risk factors decreases complications that may occur with the desease. Objectives: To determine the related risk factors of epistaxis and its frequency among children aged 6-12 in Lower Egypt. Methods: a cross-sectional study was conducted on 758 children. Using multistage sampling technique, Sharkia and Menoufia governorates were selected to represent Lower Egypt, Zagazig and Shebin El-Kom health districts were selected, then four family health facilities were chosen to represent urban and rural areas. Data on participants' socio-demographic characteristics, characteristics of epistaxis attacks and many related risk factors were collected via a semi-structured questionnaire. Results: The study revealed a high frequency of epistaxis (35.4\%) among children aged 6-12. About $(53.3 \%)$ of them were of low socioeconomic standard. The attacks were more frequent in winter $(43.7 \%)$, and most of them were of a little amount of bleeding. the risk was more evident with head and face trauma, exposure to cigarette smoke, children suffering from chronic coughing or nasal allergy, or using steroid-containing drugs. Conclusion: There is a high frequency of epistaxis among young children. Most of the related risk factors are easily modifiable to prevent the recurrence of the attacks. Health education related to children's safety measures along with fostering awareness about epistaxis red flags is still needed.

Keywords: allergic rhinitis, frequency, Lower Egypt, Nosebleed, Trauma.

Introduction: nearly two thirds by age of $15 .^{(2)}$ The high

Epistaxis or nostril hemorrhage is a common complaint in children. Epistaxis can be divided into anterior bleeding (the most common) and posterior bleeding according to where the bleeding originates. ${ }^{(1)}$

Epistaxis is rare before 2 years of age, and its incidence increases with age, $30 \%$ of all children aged $0-5$, over half of the children have had at least one attack of epistaxis by the age 10 and prevalence of epistaxis among children is due to their extremely well-vascularized nasal mucosa with contributions from the tributaries of both the internal and external carotid arteries, plexus of Kiesselbach in Little's area of the anterior nasal septum is the most common source of bleeding, and the cause of the increased frequency of upper respiratory tract infection. ${ }^{(3)}$ It is rarely a dangerous condition but may cause significant

*Corresponding author: E-mail: drhanasalah@yahoo.com 
concern, especially among parents of young children. Most of the epistaxis attacks are not dangerous, self-limiting, and spontaneous, but some can be recurrent, also there are uncommon causes that may be noted. ${ }^{(4)}$

The etiology of epistaxis can be due to local causes as mucosal irritation, trauma, septal abnormality, inflammatory and allergic diseases, and tumors. Traumatic epistaxis is common in children, and is most often due to digital manipulation, facial injury, or a foreign body in the nasal cavity. Non-traumatic risk factors are less common in children and may be due to systemic diseases and environmental factors (e.g. temperature, humidity) $)^{(5)}$, and the term "Idiopathic Epistaxis" represents about $80-90 \%$ of the cases. ${ }^{(6)}$

Epistaxis in children is a common problem for both primary care physicians and otolaryngologists. Although epistaxis is a frequent reason for referral to Otolaryngologists, data is lacking regarding risk factors causing it.

The objective of the current study aimed to to identify epistaxis risk factors and its frequency among children aged 6-12 in Lower Egypt.

\section{Method:}

\section{Study design and sampling method:}

This study is a cross-sectional study. The sample was calculated to be 758 children (aged 6- 12) based on a epistaxis prevalence of $56 \%{ }^{(1)}$. The total number of children of the same age group of lower Egypt was 5785020 child according to Egyptian census $2017^{(7)}$, using online open epi program at $95 \%$ confidence level and 5\% margin of error.

Through a multistage cluster sampling technique, Sharkia and Menoufia governorates were selected to represent lower Egypt, Menoufia governorate was divided administratively to ten health directorates, Shebin El-Kom health directorate was selected as it represents the capital district of the governorate. In the same way, Zagazig health directorate was selected to represent Sharkia governorate (which was divided administratively to 19 health directorates); Zagazig health directorate represents the capital district of the governorate.

Four family health facilities were selected randomly (two facilities from each district) to represent urban and rural areas, children contributed to the study 
were collected randomly from each health facility according to the attendance rate by proportional allocation method.

\section{Study participants and data collection:}

The study included children (aged 6-12 years) attending the selected health facilities asking for medical advice for any reason, children's caregivers (e.g. mother) were interviewed using a semistructured questionnaire modified from (Iqbal and Ahmed, 2015). ${ }^{(1)}$ The questionnaire was validated by panels of experts in community and family medicine departments. The questionnaire consisted of socio-demographic assessment questions according to the scoring system of Fahmy et al., 2015 ${ }^{(8)}$ and questions about medical history of cases as occurrence of epistaxis, frequency of attacks, amount of bleeding, and its relation to the studied risk factors as history of trauma, positive family history and consanguinity, medications, septal abnormalities, inflammatory diseases, nasal irritations and systemic causes.

Social class was classified according to Fahmy and colleagues ${ }^{(8)}$ into high (33.6-48), medium (19.2-<33.6), and low (<19.2) depending on the score calculated. A pilot study (10\% of the total sample) was implemented to estimate the time needed to obtain the required information, and there was no administrative or technical obstacles founded (the total sample included the pilot sample). The questionnaire took about 15 minutes to be completed. The whole study was implemented at a period of 7 months (from May to November 2019). The study was approved by ElSharkia and El-Menoufia health directorate. An official permission letter was obtained from the authorities and directed to the health facilities included in the study.

Ethical Approval: Informed written consent was obtained from the children's caregivers and an verbal consent was obtained from the child himself after simple clarification of the study objectives and methodology. Official approval from the Institutional review board (IRB) was taken (ZU-IRB \#5730)

Statistical analysis: All data were collected, tabulated and statistically analyzed using Statistical Package of Social Science (SPSS) version 20.0 for Windows (SPSS Inc., Chicago, IL, USA). 
The following statistics were applied: Student t-test was used for comparing quantitative variables with independent parametric data, expressed as mean and standard deviation, while Fischer Exact test or Chi-square was applied for qualitative variables expressed as percentage. Multivariate logistic regression analysis was used to detect the most evident risk factor.

\section{Results:}

During the study period, 758 children's caregivers were interviewed to assess the frequency and determine the risk factors of epistaxis among their children in Lower Egypt. The frequency of epistaxis among the children was $35.4 \%$ (figure 1). About half of the studied children who experienced epistaxis were less than eight years old and of middle socioeconomic standard and about $66 \%$ were males (Table 1).

Nearly half of the children with epistaxis had a similar history in their families and about $37.3 \%$ had positive consanguinity. Other common risk factors identified were local causes including head and face trauma (92.5\%), local nasal spray (66.4\%), septal deviation (29.1\%), nasal allergy (72.4\%), recurrent respiratory infection $(51.5 \%)$, chronic cough $(50.7 \%)$, steroid containing drugs $(52.2 \%)$, exposure to cigarette smoke $(84.3 \%)$ and industrial smoke (19.0\%). Also, Systemic causes of epistaxis included bleeding tendency $(4.1 \%)$, history of vascular diseases (36.2\%), history of liver disease and migraine (4.1\%) (Table 2).

On performing multivariate logistic regression analysis of the common risk factors for developing epistaxis, the risk was more evident with head and face trauma $(\mathrm{OR}=82.1$ with $\mathrm{CI}(0.02-13.2)$ followed by cigarette smoke exposure $(\mathrm{OR}=51.7$ with $\mathrm{CI}(0.04-15)$ then who were suffering from chronic cough $(\mathrm{OR}=18.6$ with CI ( 2.67-14.9)then nasal allergy $(\mathrm{OR}=17.8$ with $\mathrm{CI}(0.05-3.2)$ then receiving steroid containing drugs $(\mathrm{OR}=17.2$ with $\mathrm{CI}$ ( 0.06-3.9) (Table 3).

The mean age of the symptomatic children at the first attack was $3.2 \pm 1.5$ and the mean number of attacks was 3.9 \pm 1.7 . About $85 \%$ of the children experienced a little amount of bleeding that did not require medical attention from the viewpoint of their caregivers. The attack was more frequent in Winter 
(43.7\%) followed by Autumn (35.4\%)

(Table 4).

\section{Discussion:}

Epistaxis is a common rhinological presentation; it is a major challenge in pediatric, otorhinolaryngology and family practice because of its high incidence in young children, alarming presentation and its tendency to recur. ${ }^{(4)}$

The result of the current study revealed that about one-third of children aged 6-12 years old were exposed at least to a single attack of epistaxis. This is similar to the results of a previous study that was done in Uganda that reported that the frequency of epistaxis among a control group of children was $23.4 \% .^{(9)}$ In contrast, a study done in the United States to detect epidemiology of epistaxis revealed that only $6 \%$ of children under the age of 15 had an epistaxis attack. ${ }^{(10)}$ Many studies revealed that the actual prevalence of epistaxis is not known as fortunately most of the attacks are selflimited and the patients do not seek medical examination. ${ }^{(11)}$

There was no statistical significance for the correlation between epistaxis occurance and sex, this disagrees with a prospective study conducted in Nigeria that clarified that males are one and half times more liable to epistaxis than females and attributed that to overexposure to injuries as they are highly adventurous group $^{(5)}$, Another study done in Bangladesh proved that boys are two times more prone to epistaxis than girls. ${ }^{(12)}$

Most of the affected children are of low and middle social class, and this result is in accordance with research conducted in Bangladesh that refers to poor environmental conditions and maltreatment of inflammatory and allergic upper respiratory diseases as one important risk factor for the desease. ${ }^{(12)}$

Head and face trauma is the most frequent risk factor causing epistaxis in almost all cases $(92.5 \%)$, followed by exposure to cigarette smoke, nasal allergy, use of local nasal spray, especially steroidbased sprays, and recurrent upper respiratory infection. In contrast a study done in Bangladesh revealed that inflammatory diseases (46\%) especially upper respiratory conditions $(28 \%)$ are the most frequent associated risk factor of epistaxis in children followed by nasal trauma and nasal allergy ${ }^{(12)}$. Another study done in Saudi Arabia which found that 
inflammatory diseases are the most common risk factor $(50.5 \%)$ followed by upper respiratory infection $(15.2 \%)$ and nasal trauma $(11.4 \%){ }^{(13)}$

The multivariate logistic regression analysis revealed that head and face trauma, cortisone containing drugs, nasal allergy, exposure to cigarette smoke, and chronic cough are highly significant risk factors causing epistaxis attacks in children. Similar results were reported in a Japanese study ${ }^{(14)}$ that revealed that the cause of epistaxis in children is usually from picking, rubbing, and hitting their nose.

A systematic review study done in 2013 confirms that most cases of epistaxis occur due to local trauma (including nose-picking), local allergy or inflammation and mucosal drying. ${ }^{(15)}$

The current study revealed that the majority of the epistaxis attacks were of a little amount of blood, self-limited, and mostly occurred in winter or autumn seasons. This was in accordance with McGarry ${ }^{(15)}$ which reported that most of the epistaxis attacks in children occur from the anterior part of the septum in the region of Little's area, which are selflimited and about $9 \%$ of children aged 7 -
11 years had frequent episodes of epistaxis. These results are also similar to Messner AH. ${ }^{(16)}$, who revealed the common association of epistaxis in children in the winter season which in turn is associated with a high incidence rate of allergic rhinitis and upper respiratory infections.

Conclusion: Epistaxis is a common health problem among children, commonly self-limited. Most of its risk factors are controllable and preventable.

Recommendations: Health education messages about the most common risk factors for epistaxis should be disseminated widely among susceptible children's caregivers. Safety measures are mandatory at home and in schools to decrease accidental trauma. Children with nasal allergy and chronic cough should receive adequate control medications and use alternatives for steroid-containing drugs.

Study limitation: Lack of cooperation from some children's caregivers, but the researchers persuaded them to participate in the study after explaning the study's significans, objectives, and methodology. 
Acknowledgment: we would like to express great thanking to the participants and health facilities' staff for their help to accomplish this work.

Funding: there has been no financial support for this work that could have influenced its outcome.

Conflict of interest: there are no known conflicts of interest associated with this publication.

\section{References:}

1.Iqbal M, Ahmed W. Epistaxis: Its Prevalence in IDPs of North Waziristan Agency. American Journal of Clinical and Experimental Medicine. 2015 Oct 9;3(5):233.

2.Fuller CW, Prosser JD. Epistaxis in Children: Evaluation and Management. Current Treatment Options in Pediatrics. 2018 Jun 1;4(2):203-10.

3.Messner AH, Singer JI. Causes of epistaxis in children. UpToDate [Internet]. Uptodate.com. 2019 [cited June 2019]. Available from: https://www.uptodate.com/contents/e pidemiology-and-etiology-ofepistaxis-in-children.

4.Wahab MS, Fathy H, Ismail R et al. Recurrent epistaxis in children: When should we suspect coagulopathy?. The Egyptian Journal of Otolaryngology. $2014 \quad$ Apr 1;30(2):106.

5.Adegbiji WA, Olajide GT, Olatoke F et al. Clinico-Epidemiological Pattern and Treatment of Epistaxis in a Tertiary Hospital in South Western Nigeria. International Journal of Otolaryngology and Head \& Neck Surgery. 2018;7:1-0

6.Gilyoma JM, Chalya PL. Etiological profile and treatment outcome of epistaxis at a tertiary care hospital in Northwestern Tanzania: a prospective review of 104 cases. BMC ear, Nose and throat Disorders. 2011 Dec;11(1):8.

7. Egypt census 2017, 201710914947book.pdf. Available at: $\quad$ www.CAPMAS.gov.eg,. Accessed on May 2019.

8.Fahmy SI, Nofal LM, Shehata SF et al. Updating indicators for scaling the socioeconomic level of families for health research. Journal of the Egyptian Public Health Association. 2015 Mar 1;90(1):1-7.

9.Nardo-Marino A, Williams TN, Olupot-Olupot P. The frequency and 


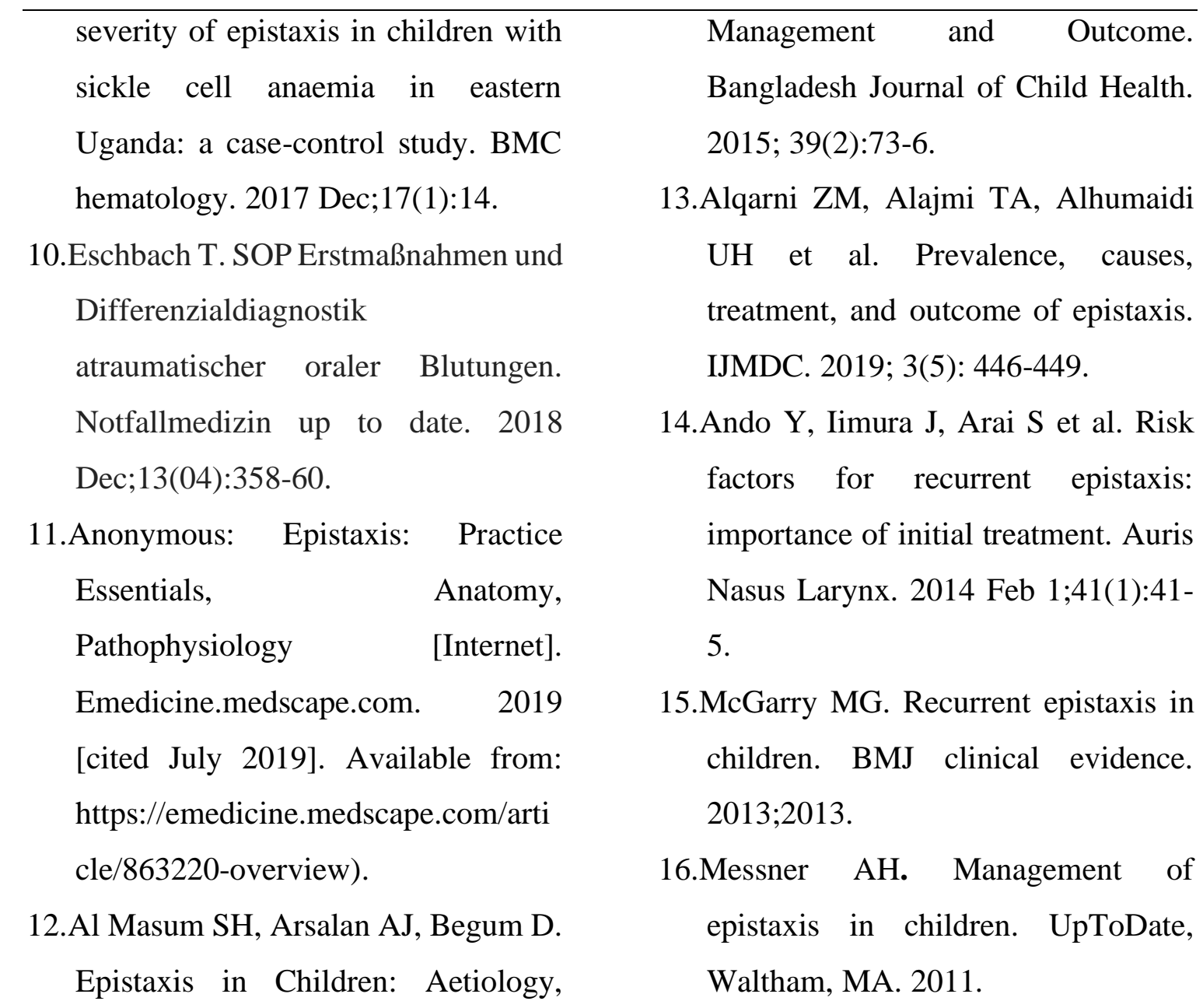


Table (1): Sociodemographic characteristics of the studied groups

\begin{tabular}{|c|c|c|c|c|c|c|c|c|}
\hline \multirow[t]{2}{*}{ Variable } & \multicolumn{2}{|c|}{$\begin{array}{l}\text { Without } \\
\text { epistaxis } \\
\text { (490) }\end{array}$} & \multicolumn{2}{|c|}{$\begin{array}{l}\text { With epistaxis } \\
\text { (268) }\end{array}$} & \multicolumn{2}{|c|}{$\begin{array}{l}\text { Total } \\
758\end{array}$} & \multirow[t]{2}{*}{$\mathrm{X} 2$} & \multirow[t]{2}{*}{ P-value } \\
\hline & No & $\%$ & No & $\%$ & No & $\%$ & & \\
\hline \multirow{2}{*}{$\begin{aligned} & \text { Age: } \\
& \text { - } \quad 6-<8 \\
& \text { : } 8-12 \\
& \text { Mean } \pm \text { SD }\end{aligned}$} & $\begin{array}{l}251 \\
239\end{array}$ & $\begin{array}{l}51.2 \\
48.8\end{array}$ & $\begin{array}{l}140 \\
128\end{array}$ & $\begin{array}{l}52.2 \\
47.8\end{array}$ & $\begin{array}{l}391 \\
367\end{array}$ & $\begin{array}{l}51.6 \\
48.4\end{array}$ & 0.07 & 0.42 \\
\hline & \multicolumn{2}{|c|}{$8.7 \pm 2.1$} & \multicolumn{2}{|c|}{$8.6 \pm 1.6$} & \multicolumn{2}{|c|}{$8.7 \pm 1.9$} & & \\
\hline $\begin{array}{ll}\text { Sex: } & \\
\text { - } & \text { Male } \\
\text { - } & \text { Female }\end{array}$ & $\begin{array}{l}324 \\
166\end{array}$ & $\begin{array}{l}66.1 \\
33.9\end{array}$ & $\begin{array}{l}178 \\
90\end{array}$ & $\begin{array}{l}66.4 \\
33.6\end{array}$ & $\begin{array}{l}502 \\
256\end{array}$ & $\begin{array}{l}66.2 \\
33.8\end{array}$ & 0.007 & 0.5 \\
\hline 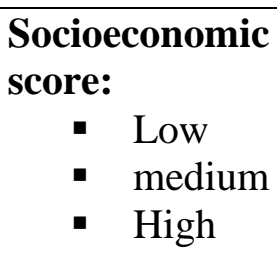 & $\begin{array}{l}300 \\
179 \\
11\end{array}$ & $\begin{array}{l}61.2 \\
36.5 \\
2.2\end{array}$ & $\begin{array}{l}94 \\
126 \\
48\end{array}$ & $\begin{array}{l}35.1 \\
47.0 \\
17.9\end{array}$ & $\begin{array}{l}394 \\
305 \\
59\end{array}$ & $\begin{array}{l}52.0 \\
40.2 \\
7.8\end{array}$ & 82.15 & $<0.001$ \\
\hline
\end{tabular}


Table (2): Univariate analysis of epistaxis risk factors

\begin{tabular}{|c|c|c|c|c|c|c|c|}
\hline \multirow[t]{2}{*}{ Variable } & \multicolumn{2}{|c|}{$\begin{array}{l}\text { Without } \\
\text { epistaxis }\end{array}$} & \multicolumn{2}{|c|}{$\begin{array}{l}\text { With } \\
\text { epistaxis }\end{array}$} & \multirow[t]{2}{*}{$\mathbf{X} 2$} & \multirow[t]{2}{*}{$P$ value } & \multirow[t]{2}{*}{$\begin{array}{l}\text { OR * } \\
(\text { CI 95\%) }\end{array}$} \\
\hline & $\begin{array}{l}\text { No } \\
(490)\end{array}$ & $\%$ & $\begin{array}{l}\text { No } \\
(268)\end{array}$ & $\%$ & & & \\
\hline $\begin{array}{l}\text { Positive Family } \\
\text { history of epistaxis }\end{array}$ & 19 & 3.9 & 144 & 53.7 & 14.9 & $<0.001$ & $\begin{array}{l}28.79 \\
(17.15-48.31)\end{array}$ \\
\hline $\begin{array}{l}\text { - Positive } \\
\text { Consanguinity }\end{array}$ & 19 & 3.9 & 100 & 37.3 & 28.1 & $<0.001$ & $\begin{array}{l}14.76 \\
(8.76-24.85)\end{array}$ \\
\hline $\begin{array}{lll}\text { Head and face } \\
\text { trauma }\end{array}$ & 114 & 32.3 & 248 & 92.5 & 14.5 & $<0.001$ & $\begin{array}{l}40.89 \\
(24.76-67.53)\end{array}$ \\
\hline $\begin{array}{l}\text { - Steroid containing } \\
\text { drugs }\end{array}$ & 36 & 7.3 & 140 & 52.2 & 12.4 & $<0.001$ & $\begin{array}{l}13.79 \\
(9.1-20.89) \\
\end{array}$ \\
\hline - Local nasal spray & 77 & 15.7 & 178 & 66.4 & 13.2 & $<0.001$ & $\begin{array}{l}10.6 \\
(7.47-15.07)\end{array}$ \\
\hline - Septal deviation & 38 & 7.8 & 78 & 29.1 & 7.3 & $<0.001$ & $\begin{array}{l}4.88 \\
(3.19-7.46)\end{array}$ \\
\hline - Nasal allergy & 76 & 15.5 & 194 & 72.4 & 244.4 & $<0.001$ & $\begin{array}{l}14.28 \\
(9.94-20.52)\end{array}$ \\
\hline $\begin{array}{ll}\text { - } & \text { Recurrent } \\
& \text { respiratory infection }\end{array}$ & 72 & 14.7 & 138 & 51.5 & 117.1 & $<0.001$ & $\begin{array}{l}6.16 \\
(4.36-8.71)\end{array}$ \\
\hline $\begin{array}{ll}\text { - } & \begin{array}{l}\text { Cigarette } \\
\text { exposure }\end{array} \\
\end{array}$ & 79 & 16.1 & 226 & 84.3 & 335.2 & $<0.001$ & $\begin{array}{l}27.99 \\
(18.62-42.09)\end{array}$ \\
\hline - Industrial smokes & 23 & 4.7 & 51 & 19.0 & 40.4 & $<0.001$ & $\begin{array}{l}4.77 \\
(2.84-8.01)\end{array}$ \\
\hline - Chronic cough & 72 & 14.7 & 136 & 50.7 & 113.1 & $<0.001$ & $\begin{array}{l}5.98 \\
(4.23-8.46)\end{array}$ \\
\hline - Bleeding tendency & 0 & 0.0 & 11 & 4.1 & ------ & -------- & ------- \\
\hline - Anticoagulant drugs & 0 & 0.0 & 4 & 1.5 & ------ & \begin{tabular}{|l}
------- \\
\end{tabular} & ---------- \\
\hline $\begin{array}{l}\text { History of vascular } \\
\text { diseases }\end{array}$ & 8 & 1.6 & 97 & 36.2 & $173.4 * *$ & $<0.001$ & $\begin{array}{l}34.18 \\
(16.28-71.76) \\
\end{array}$ \\
\hline $\begin{array}{l}\text { - } \begin{array}{l}\text { History of liver } \\
\text { disease }\end{array} \\
\end{array}$ & 0 & 0.0 & 11 & 4.1 & ------- & \begin{tabular}{|l|}
------- \\
\end{tabular} & --------- \\
\hline - History of migraine & 0 & 0.0 & 11 & 4.1 & $\begin{array}{l}------ \\
\end{array}$ & -------- & --------- \\
\hline
\end{tabular}

* Odds Ratio, Confidence Interval

** Fisher exact test 
Table (3): Multivariate logistic regression for risk factors of epistaxis in 6-12 years old children

\begin{tabular}{|c|c|c|c|c|c|}
\hline Independent factors & $\mathrm{B} *$ & Wald & $\mathrm{OR} * *$ & $\begin{array}{l}\text { CI 95\% ** } \\
\text { (lower-upper) }\end{array}$ & $\mathrm{P}$ value \\
\hline - Positive Consanguinity & 0.76 & 2.15 & 3.42 & $0.02-1.1$ & 0.06 \\
\hline - Positive Family history & 0.81 & 2.09 & 3.41 & $0.04-1.8$ & 0.08 \\
\hline $\begin{array}{c}\text { - Socioeconomic score: } \\
\circ \text { Low and medium } \\
\circ \text { High* }\end{array}$ & 2.04 & 3.48 & 1.04 & $0.94-2.93$ & 0.05 \\
\hline - Head and face trauma & 4.98 & 14.85 & 82.1 & $2.19-13.2$ & $<0.001 * * *$ \\
\hline - Cortisone containing drugs & 1.01 & 8.47 & 17.2 & $1.06-3.9$ & $<0.001 * * *$ \\
\hline - Local nasal spray & 0.43 & 1.18 & 1.05 & $0.44-1.8$ & 0.8 \\
\hline - Septal deviation & 0.73 & 0.77 & 3.38 & $0.2-1.05$ & 0.07 \\
\hline - Nasal allergy & 1.12 & 9.12 & 17.8 & $1.4-3.2$ & $<0.001 * * *$ \\
\hline - Recurrent respiratory infection & 0.002 & 0.076 & 1.06 & $0.39-2.05$ & 0.8 \\
\hline - Cigarette smoke exposure & 3.18 & 13.21 & 51.7 & $1.94-5.15$ & $<0.001 * * *$ \\
\hline - Industrial smokes & 1.01 & 2.07 & 1.9 & $0.16-1.36$ & 0.16 \\
\hline - Chronic cough & 1.54 & 11.19 & 18.6 & $2.76-4.97$ & $<0.001 * * *$ \\
\hline - Bleeding tendency & 0.07 & 0.02 & 1.001 & 0.000 & 0.9 \\
\hline - Anticoagulant drugs & 0.72 & 1.98 & 1.006 & 0.000 & 0.4 \\
\hline - History of vascular diseases & 2.03 & 3.78 & 1.25 & $0.64-5.1$ & 0.2 \\
\hline - History of liver disease & 2.03 & 3.78 & 1.25 & $0.64-5.1$ & 0.2 \\
\hline - History of migraine & 0.72 & 1.98 & 1.6 & 0.000 & 0.4 \\
\hline
\end{tabular}

B: Beta coefficient (it's a regression not ANOVA)

** OR: Odds Ratio

*** Statistically significant
* Reference group

CI: Confidence Interval 
Table (4): Criteria of epistaxis attack

\begin{tabular}{|c|c|c|}
\hline Item & $\begin{array}{c}\text { No } \\
(268)\end{array}$ & $(\%)$ \\
\hline $\begin{array}{c}\text { Age at the first attack } \\
\text { - Mean } \pm \text { SD } \\
\text { - Median } \\
\text { - Range }\end{array}$ & $\begin{array}{l}3.2 \pm 1.5 \\
3 \\
5\end{array}$ & \\
\hline $\begin{array}{c}\text { Number of attacks } \\
\text { - Mean } \pm \text { SD } \\
\text { - Median } \\
\text { - Range }\end{array}$ & $\begin{array}{l}3.9 \pm 1.7 \\
3 \\
8\end{array}$ & \\
\hline $\begin{array}{l}\text { Amount of bleeding (by } \\
\text { caregiver perception): } \\
\text { - little amount } \\
\text { - Moderate amount } \\
\end{array}$ & $\begin{array}{l}229 \\
39 \\
\end{array}$ & $\begin{array}{l}85.4 \\
14.6 \\
\end{array}$ \\
\hline $\begin{array}{l}\text { The attack appears mostly in: } \\
\text { - Winter } \\
\text { - Summer } \\
\text { - Spring } \\
\text { - } \text { Autumn }\end{array}$ & $\begin{array}{l}117 \\
40 \\
16 \\
95\end{array}$ & $\begin{array}{l}43.7 \\
14.9 \\
6.0 \\
35.4\end{array}$ \\
\hline
\end{tabular}

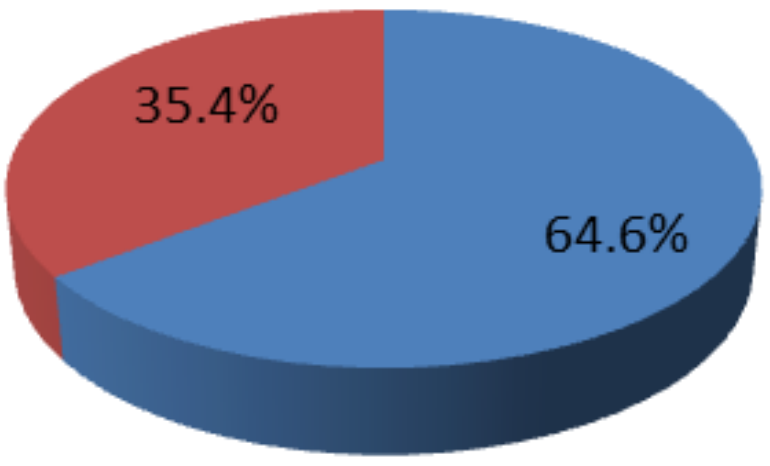

without epistaxis

with epistaxis

Figure (1): Frequency of epistaxis in 6-12 years old children 


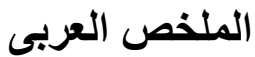

\section{النزف من الأنف عند الأطفال فى الوجه البحرى مصر: معدل الانتشار وعوامل الخطورة}

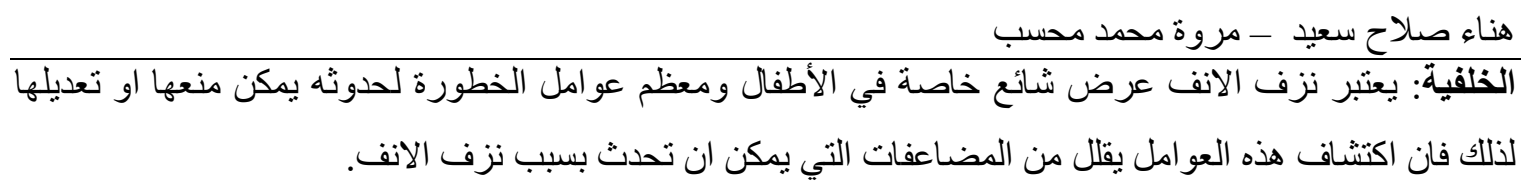
المنهجية وطرق البحث: أجريت هذه الدراسة لتحديد عوامل خطورة نزف الانف بين الأطفال من سن 6 الي 12عام في الوجه البحري وتحديد معدل انتشاره ـ وقد تمت هذه الدر اسة العرضية على 758 طفل بحساب عينة متعددة المر احل حيث اختيرت الثرقية والمنوفية كمحافظتين ممثلنين للوجه البحري وتم اختيار الزقازيق وشبين الكوم كمر اكز داخل المحافظتين لعمل الدراسة ثم تم اختيار أربعة مرافق صحية لتمثيل مناطق الريف والحضر بهذه المر اكز ثم تم جمع البيانات الديمو غر افية لتحديد مستوي المعيشة وبيانات خاصة بخصائص نوبات نزف الانف و عو امل خطورة حدوثنه عن طريق استبيان تمت صياغته. النتائج: وقد أظهرت النتائج وجود معدل انتشار عال للمرض يصل الي 35.4\% بين الأطفال من سن 6 الي 12 سنة منهم 53.3\% في مستوي اجتماعي منخفض. وقد لوحظ حدوث المرض بصورة أكبر في الثتاء (43.7\%) ولكن كمية النزف قليلة ومن اهم عوامل خطورة نزف الانف إصابة الر أس و الوجه و التعرض لاخخان السجائر ومعاناة الأطفال من كحة مزمنة وحساسية الانف واستخدام ادوية تحتوي على مادة الكورتيزون. الخلاصة: نظهر الدراسة معدل انتشار عال لنزف الأنف بين الأطفال مع وجود عو امل خطورة والتي معظمها قابلة للتعديل لمنع تكرار حدوث المرض. كمازلنا بحاجة الي التثقيف الصحي بخصوص توفير اجراءات السلامه للأطفال مع زيادة الوعي حول علامات الخطر. 